\title{
GMR
}

\section{Effects of glial cell line-derived neurotrophic factor and leukemia-inhibitory factor on the behavior of two calf testis germline stem cell colony types}

P. Zheng, H. Huang, Y.G. Tian, Y. Zeng, E.O. Adegoke, X. Wang and G.X. Zhang

College of Animal Science and Technology, Northeast Agricultural University, Harbin, China

Corresponding author: G.X. Zhang

E-mail: gxzhang@neau.edu.cn

Genet. Mol. Res. 15 (4): gmr15048856

Received June 6, 2016

Accepted July 25, 2016

Published October 17, 2016

DOI http://dx.doi.org/10.4238/gmr15048856

Copyright (C 2016 The Authors. This is an open-access article distributed under the terms of the Creative Commons Attribution ShareAlike (CC BY-SA) 4.0 License.

\begin{abstract}
Germline stem cells are the only such capable of transmitting genetic information in vivo. The isolation and culture of these cells in vitro provide a unique model to understand sperm differentiation and hence, spermatogenesis and male fertility. In this study, we isolated, purified, and cultured germline stem cells from the testes of newborn calves. Moreover, we investigated the effects of glial cell line-derived neurotrophic factor (GDNF) and leukemia-inhibitory factor (LIF) on their proliferation. Male calf germline stem cells were found to be pluripotent, and able to form grape-like and embryonic stem cell (ES)-like colonies when cultured. GDNF promoted proliferation of the former, whereas LIF induced growth of the latter. The grapelike colonies retained their germline stem cell characteristics, whereas
\end{abstract}


the ES-like colonies demonstrated more primitive attributes. This investigation established a male calf germline stem cell culture model that may serve as a foundation for further studies aiming to understand the properties of such cells.

Key words: Calf testis; Germline stem cells; Sperm differentiation; Glial cell line-derived neurotrophic factor; Leukemia-inhibitory factor; Proliferation

\section{INTRODUCTION}

Culturing and inducing the differentiation of male germline stem cells constitute highly valuable techniques for the cloning of mammals, conservation of endangered species, production of transgenic animals, and treatment of male sterility and certain hereditary diseases by gene therapy (Olive and Cuzin, 2005; Kubota and Brinster, 2006; Honaramooz et al., 2008; Zhao et al., 2010). The induced differentiation of germline stem cells into specific cell types may serve as a source of seed cells for regenerative medicine (Kossack et al., 2009; Simon et al., 2009). Although germline stem cells from several mammalian species have been studied (Kubota et al., 2004; Guan et al., 2006; Seandel et al., 2007; Goel et al., 2009), the initial groundbreaking investigations describing their isolation and purification (Izadyar et al., 2002b; Herrid et al., 2009), cryopreservation (Izadyar et al., 2002a; Kim et al., 2015), autologous (Izadyar et al., 2002a) and allogeneic transplantation (Herrid et al., 2006), and in vitro differentiation (Aponte et al., 2008; Zheng et al., 2015) were performed in cattle. However, there are few reports of germline stem cell pluripotency in this species (Aponte et al., 2008; Zheng et al., 2015). To expand on our earlier studies of the isolation, culture, and differentiation of these cells (Zheng et al., 2013, 2015), we herein describe the behavior and pluripotency of germline stem cells isolated from newborn calves and cultured in the presence of growth factors. Kanatsu-Shinohara et al. (2004) reported that glial cell line-derived neurotrophic factor (GDNF) and leukemia-inhibitory factor (LIF) can affect the proliferation and differentiation of germline stem cells isolated from mouse neonates. However, the behavior of germline stem cells from different mammalian species varies, and depends on the biological context (Izadyar et al., 2002a; Kanatsu-Shinohara et al., 2004; Seandel et al., 2007; Goel et al., 2009). To the best of our knowledge, no report concerning the roles of LIF and GDNF in the proliferation and differentiation of calf germline stem cells has been published. Therefore, in this study, we isolated and cultured such cells in the presence or absence of these factors. Their effects were tested by observing the growth and developmental characteristics of germline stem cells and the expression levels of protein gene product 9.5 ( $P g p$ 9.5), GDNF family receptor alpha 1 (Gfral), octamer-binding transcription factor 4 (Oct-4), sex-determining region Y-box 2 (Sox2), Nanog homeobox (Nanog), and deleted in azoospermia-like (Dazl).

\section{MATERIAL AND METHODS}

\section{Materials}

Cell culture reagents were purchased from Sigma-Aldrich (St. Louis, MO, USA). The testes of six healthy Holland Holstein calves (Harbin Modern Biological Technical Co., Ltd.,

Genetics and Molecular Research 15 (4): gmr15048856 
Harbin, China) were obtained within $24 \mathrm{~h}$ after birth. The newborn calves were bled to death, their abdomens disinfected with iodine, and their testes harvested. The testes were cut from the fat pad and rinsed several times in physiological saline pre-warmed to $37^{\circ} \mathrm{C}$, in which they were then transported to the laboratory, before being cooled to $4^{\circ} \mathrm{C}$ within $2 \mathrm{~h}$. This study was undertaken in accordance with the guidelines of the Animal Ethics Committee of Northeast Agricultural University, Harbin, China, whose approval was obtained.

\section{Preparation of the Sertoli cell feeder layer}

We used a previously described method (Zheng et al., 2015) for the isolation and purification of Sertoli cells, which were cultured in Dulbecco's modified Eagle's medium/ nutrient mixture F-12 (DMEM/F-12) supplemented with 10\% fetal bovine serum (FBS), 2 $\mathrm{mM}$ L-glutamine, $0.1 \mathrm{mM} 2$-mercaptoethanol, and 1\% penicillin-streptomycin. After the third passage, Sertoli cells cultured for $2.5 \mathrm{~h}$ in DMEM/F-12 containing mitomycin C were digested with trypsin, transferred to Petri dishes coated with $0.2 \%$ gelatin, and cultured at $5 \times 10^{5}$ cells/ $\mathrm{mL}$ for use as the feeder layer.

\section{Isolation and purification of germline stem cells}

The two-step differential adherence method was used to isolate and purify germline stem cells as described by Zheng et al. (2015), with some modifications. Briefly, the tunica albuginea was removed, and the seminiferous tubules were rinsed in phosphate-buffered saline (PBS), before being digested twice with $1.5 \mathrm{mg} / \mathrm{mL}$ collagenase and centrifuged at 200 $g$ for 5 min. Cells were resuspended in PBS, filtered through a 74- $\mu$ m nylon mesh, and washed twice with PBS. The cells, including germline stem cells, were subsequently resuspended in DMEM/F-12 supplemented with $10 \%$ FBS and 1\% penicillin-streptomycin, and cultured on Petri dishes at $37^{\circ} \mathrm{C}$ for $3-4 \mathrm{~h}$ in a humidified atmosphere of $5 \% \mathrm{CO}_{2}$. The supernatant was then collected and centrifuged at $200 \mathrm{~g}$ for $5 \mathrm{~min}$. The pelleted germline stem cells were resuspended in DMEM/F-12, transferred to a second culture dish, and cultured for $24 \mathrm{~h}$. The cells were collected and centrifuged for further use.

\section{Primary culture and subculture of germline stem cells}

The germline stem cells obtained using the two-step differential adherence method had a purity $>90 \%$. These cells were resuspended in medium containing GDNF [DMEM/F-12 supplemented with $2 \% \mathrm{FBS}, 2 \mathrm{mM}$ L-glutamine, $0.1 \mathrm{mM}$ 2-mercaptoethanol, $1 \%$ penicillinstreptomycin, 1\% minimum essential medium (MEM) non-essential amino acids, 1\% MEM vitamins, $10 \mu \mathrm{g} / \mathrm{mL}$ insulin-transferrin-sodium selenite, $30 \mu \mathrm{g} / \mathrm{mL}$ sodium pyruvate, and 100 $\mathrm{ng} / \mathrm{mL}$ GDNF]. The density was adjusted to $5 \times 10^{5}$ cells $/ \mathrm{mL}$, and cells were cultured on Petri dishes at $37^{\circ} \mathrm{C}$ in a humidified atmosphere of $5 \% \mathrm{CO}_{2}$. Germline stem cell colonies were established after 1 week.

These colonies were digested with collagenase and transferred to the Sertoli cell feeder layer with a sterile glass pipette. Half of the subcultures were established in medium containing GDNF, and half in that containing LIF (DMEM/F-12 supplemented with 2\% FBS, $2 \mathrm{mM}$ L-glutamine, $0.1 \mathrm{mM}$ 2-mercaptoethanol, 1\% penicillin-streptomycin, 1\% MEM nonessential amino acids, $1 \%$ MEM vitamins, $10 \mu \mathrm{g} / \mathrm{mL}$ insulin-transferrin-sodium selenite, 30

Genetics and Molecular Research 15 (4): gmr15048856 
$\mu \mathrm{g} / \mathrm{mL}$ sodium pyruvate, and $1000 \mathrm{IU} / \mathrm{mL}$ LIF). The medium was changed twice per week. To characterize colonies, subcultures were subjected to reverse transcription-polymerase chain reaction (RT-PCR), alkaline phosphatase (AKP) staining, and OCT-4 immunostaining.

\section{Staining of AKP, OCT-4, and microtubule-associated protein-2 (MAP-2) in germline stem cells and colonies}

AKP was stained using a specific kit (Cat. No. ZLI9041; Beijing Zhongshan Jinqiao Co., Beijing, China) following the manufacturer protocol. OCT-4 and MAP-2 were immunostained in germline stem cells and colonies using monospecific antibodies.

In brief, cells and colonies were fixed in 4\% paraformaldehyde for $15 \mathrm{~min}$, washed twice with $0.1 \%$ bovine serum albumin (BSA) in PBS for 5 min, and blocked with 5\% BSA in PBS at room temperature for $40 \mathrm{~min}$. Thereafter, specimens were incubated overnight at $4^{\circ} \mathrm{C}$ with a rabbit anti-OCT-4 antibody (1:500 dilution; Santa Cruz Biotechnology, Dallas, TX, USA) or a mouse anti-MAP-2 antibody (1:500 dilution; Santa Cruz Biotechnology).

After washing, specimens were incubated with fluorescein isothiocyanate-labeled goat anti-rabbit or anti-mouse immunoglobulin $\mathrm{G}$ antibodies (Santa Cruz Biotechnology) at room temperature in the dark for $1 \mathrm{~h}$. Following further washing, the specimens were mounted and examined under a fluorescent microscope. Primary and secondary antibodies were prepared in $1 \%$ BSA in PBS. PBS served as the negative control.

\section{RT-PCR analysis of Pgp 9.5, Gfra1, Oct-4, Sox2, Nanog, and Dazl expression}

RNA was isolated from Sertoli cells, germline stem cells, and germline stem cell colonies with TRIzol (Invitrogen, Beijing, China), and complementary DNA generated by reverse transcription. Expression levels of Pgp 9.5, Gfral, Oct-4, Sox2, Nanog, and Dazl were detected by PCR, the products of which were analyzed on $1 \%$ agarose gels. Table 1 lists the primers used in this process. Gapdh served as a reference gene.

\begin{tabular}{|c|c|c|c|c|}
\hline Gene & Primer sequence $\left(5^{\prime}-3^{\prime}\right)$ & Product size (bp) & $\begin{array}{c}\text { Annealing } \\
\text { temperature }\left({ }^{\circ} \mathrm{C}\right)\end{array}$ & GenBank accession No. \\
\hline $\operatorname{Pgp} 9.5$ & $\begin{array}{l}\text { F: ACCCCGAGATGCTGAACAAAG } \\
\text { R: CCCAATGGTCTGCTTCATGAA }\end{array}$ & 235 & 58 & AB049188 \\
\hline Gfral & $\begin{array}{l}\text { F: CCACCAGCATGTCCAATGAC } \\
\text { R: GAGCATCCCATAGCTGTGCTT }\end{array}$ & 100 & 58 & TC213602 \\
\hline Oct-4 & $\begin{array}{l}\text { F: GGTTCTCTTTGGAAAGGTGTTC } \\
\text { R: ACACTCGGACCACGTCTTTC }\end{array}$ & 314 & 57 & NM174580 \\
\hline Sox2 & $\begin{array}{l}\text { F: GTTTGCAAAAGGGGGAAAGT } \\
\text { R: GAGGCAAACTGGAATCAGGA }\end{array}$ & 199 & 57 & NM001105463 \\
\hline Nanog & $\begin{array}{l}\text { F: TTCCCTCCTCCATGGATCTG } \\
\text { R: ATTTGCTGGAGACTGAGGTA }\end{array}$ & 219 & 58 & NM001025344 \\
\hline Dazl & $\begin{array}{l}\text { F: ACCCGCCTCTGACTCTCTCC } \\
\text { R: TGGTGGTAGCTGAAGACGACTG }\end{array}$ & 243 & 63.5 & EF501823.2 \\
\hline Gapdh & $\begin{array}{l}\text { F: ACGGCACAGTCAAGGCAGAG } \\
\text { R: GTGATGGCGTGGACAGTGGT }\end{array}$ & 375 & $58-65$ & U85042 \\
\hline
\end{tabular}

$\mathrm{F}=$ forward, $\mathrm{R}=$ reverse.

\section{In vitro formation and differentiation of embryoid bodies from two colony types}

Using the hanging drop method, embryonic stem cell (ES)-like and grape-like colonies

Genetics and Molecular Research 15 (4): gmr15048856 
were separately digested with collagenase and cultured in DMEM/F-12 supplemented with $20 \%$ FBS, $2 \mathrm{mM}$ L-glutamine, 1\% MEM non-essential amino acids, and $0.1 \mathrm{mM} 2$-mercaptoethanol. The cells of ES-like colonies aggregated into embryoid bodies, whereas those of the grapelike colonies did not. After 5 days, the embryoid bodies were transferred to six-well culture plates containing DMEM/F-12 supplemented with $10 \%$ FBS, $2 \mathrm{mM}$ L-glutamine, $0.1 \mathrm{mM}$ 2-mercaptoethanol, 1\% MEM non-essential amino acids, 1\% MEM vitamins, $10 \mu \mathrm{g} / \mathrm{mL}$ insulin-transferrin-sodium selenite, $30 \mu \mathrm{g} / \mathrm{mL}$ sodium pyruvate, $1 \%$ penicillin-streptomycin, and $10^{-7} \mathrm{M}$ retinoic acid. Differentiation of nerve cells was assessed by MAP-2 staining.

\section{Statistical analysis}

Statistical analysis was performed with the SAS software (Cary, NC, USA). Data are reported as means \pm standard errors. P values $<0.05$ were considered significant.

\section{RESULTS}

\section{Culture of primary germline stem cells}

Germline stem cells did not proliferate for the first few days after isolation. However, division was observed on day 3. After 4-5 days, the cells formed chain-like and small mulberryshaped colonies. On day 7, the chain-like colonies proliferated, forming grape-like colonies. In contrast, the small mulberry-shaped colonies proliferated to form ES-like colonies (Figure 1).

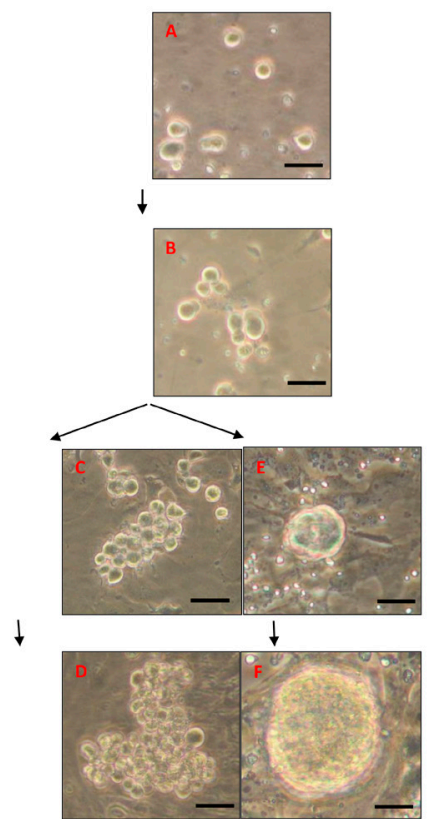

Figure 1. Culture of germline stem cells in the presence of glial cell line-derived neurotrophic factor. Germline stem cells cultured for (A) 1, (B) 3, (C) 5, and (D) 7 days. The formation of grape-like colonies was evident at days 5 and 7. Germline stem cells cultured for (E) 5 and (F) 7 days. The formation of embryonic stem cell-like colonies was evident at days 5 and 7 . Bar $=50 \mu \mathrm{m}$.

Genetics and Molecular Research 15 (4): gmr15048856 
Table 2 shows the effects of GDNF and LIF on the number of grape-like colonies after passaging of germline stem cells.

Table 2. Effects of glial cell line-derived neurotrophic factor (GDNF) and leukemia-inhibitory factor (LIF) on the number of grape-like colonies after passaging of germline stem cells $(\mathrm{N}=5)$.

\begin{tabular}{l|c|c|c}
\hline Growth factor & 4 days & 7 days & 10 days \\
\hline GDNF & $5.91 \pm 0.41^{\mathrm{A}}$ & $11.68 \pm 0.29^{\mathrm{B}}$ & $12.11 \pm 0.45^{\mathrm{B}}$ \\
\hline LIF & 0 & 0 & 0 \\
\hline
\end{tabular}

Groups with different letters are significantly different $(\mathrm{P}<0.05)$. Values represent the number of colonies on a 35-mm Petri dish.

In the presence of GDNF, germline stem cells proliferated steadily, but slowly (Figure $2)$. Although there was no significant difference $(\mathrm{P}>0.05)$ in the number of colonies at days 7 and 10 , there were significantly more at these time points than on day $4(\mathrm{P}<0.05)$. The passaged cells were positive for AKP and OCT-4 (Figure 2). In the presence of LIF, germline stem cells did not proliferate to form grape-like colonies (Table 2).

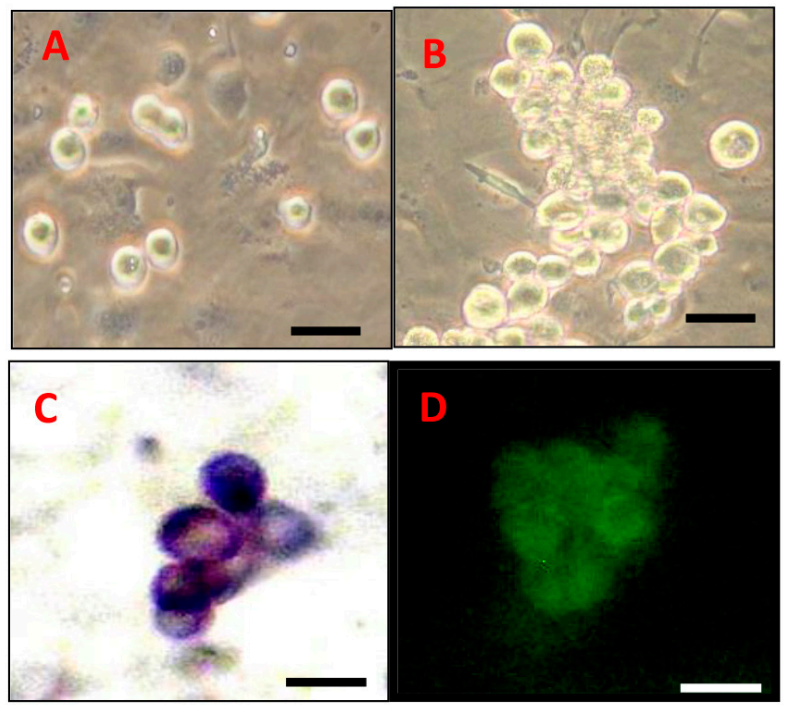

Figure 2. Passage and identification of cells from grape-like colonies. A. First and B. 7th day of subculture. Bar $(\mathrm{A}$ and $\mathrm{B})=50 \mu \mathrm{m}$. C. Alkaline phosphatase staining and D. OCT-4 immunostaining of a grape-like colony. Bar $(\mathrm{C}$ and $\mathrm{D})=20 \mu \mathrm{m}$.

\section{Effects of GDNF and LIF on the number of ES-like colonies after the passage of germline stem cells}

Table 3 shows the effects of GDNF and LIF on the number of ES-like colonies after passaging of germline stem cells.

Genetics and Molecular Research 15 (4): gmr15048856 
Table 3. Effects of glial cell line-derived neurotrophic factor (GDNF) and leukemia-inhibitory factor (LIF) on the number of embryonic stem cell-like colonies after passaging of germline stem cells $(\mathrm{N}=5)$.

\begin{tabular}{l|c|c|c}
\hline Growth factor & 4 days & 7 days & 10 days \\
\hline GDNF & 0 & 0 & 0 \\
\hline LIF & $7.1 \pm 1.6^{\mathrm{A}}$ & $3.8 \pm 1.4^{\mathrm{B}}$ & $0^{\mathrm{C}}$ \\
\hline
\end{tabular}

Groups with different letters are significantly different $(\mathrm{P}<0.05)$. Values represent the number of embryonic stem cell-like colonies on a 35-mm Petri dish.

In the presence of LIF, germline stem cells proliferated rapidly (Figure 3). The number of ES-like colonies was significantly higher $(\mathrm{P}<0.05)$ on day 4 than on day 7 . After 10 days, differentiating colonies were no longer evident. The passaged cells were positive for AKP (blue-violet) and OCT-4 (fluorescent green; Figure 3). In the presence of GDNF, germline stem cells did not grow to form ES-like colonies (Table 3).
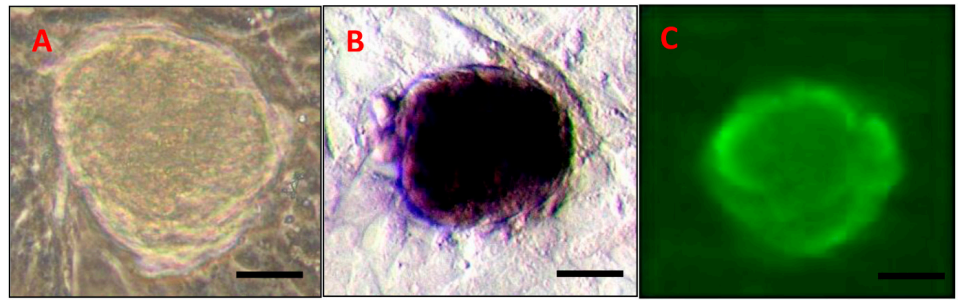

Figure 3. Formation of embryonic stem cell (ES)-like colonies and their identification. A. Passaged cells formed ES-like colonies. B. Alkaline phosphatase staining. C. OCT-4-immunostaining of an ES-like colony. Bar $=50 \mu \mathrm{m}$.

\section{Identification of pluripotent germline stem cells}

Germline stem cells and grape-like and ES-like colonies were analyzed by RT-PCR. Sertoli cells served as the negative control. Germline stem cells expressed Oct-4, Pgp 9.5, and Dazl. The grape-like colonies tested positive for Oct-4, Sox2, Gfra1, Pgp 9.5, and Dazl, but not Nanog expression. The ES-like colonies expressed Oct-4, Sox2, Nanog, Pgp 9.5, and Gfral, but not Dazl (Figure 4).

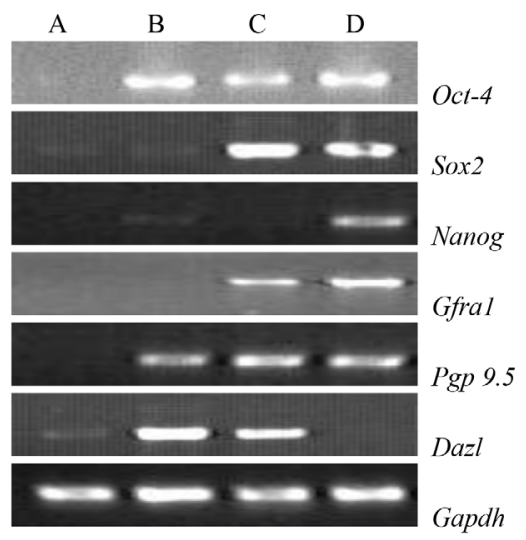

Figure 4. Reverse transcription-polymerase chain reaction analysis of germline stem cells and colonies. Lane A: Sertoli cells; lane B: germline stem cells; lane C: grape-like colonies; lane D: embryonic stem cell-like colonies. 


\section{In vitro differentiation of embryoid bodies from ES-like colonies}

Neuron-like cells were observed after culturing for 10 days. Immunocytochemistry showed that MAP-2 was present in these cells, being expressed in their axons and cell bodies (Figure 5).
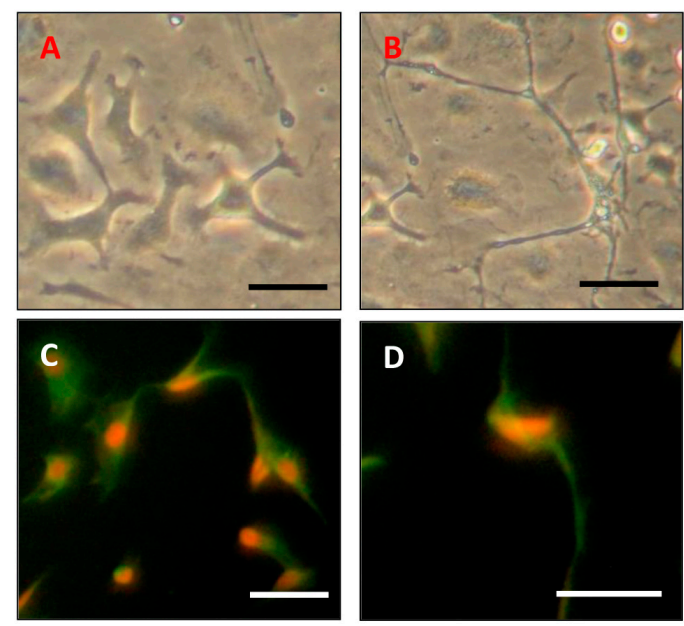

Figure 5. Differentiation of embryonic stem cell-like colonies in vitro. A. Culture of germline stem cells for 8 days, and the formation of identical precursor cells. B. Culture of germline stem cells for 11 days, and the formation of neuron-like cells. C. Culture of germline stem cells for 8 days, and the formation of neuronal precursor cells immunostained with an anti-MAP-2 antibody. D. Culture of germline stem cells for 11 days, and the formation of neurons immunostained with an anti-MAP-2 antibody. Bar $=20 \mu \mathrm{m}$.

\section{DISCUSSION}

\section{Primary culture of germline stem cells}

This study showed that germline stem cells isolated from newborn calves and cultured in vitro can form grape-like and ES-like cell colonies. This may be explained by the existence of two different germline stem cell types in neonatal bovine testes. The differentiation of one type into male germline cells may be due to asymmetric division during proliferation (Wrobel et al., 1995), and in vitro culture of these cells can result in the formation of grape-like colonies that function in spermatogenesis. The other germline stem cell type may represent residual primordial germ cells capable of forming ES-like colonies. At various stages of development and under varying conditions, the cells of these two colony forms may perform different roles. Further studies are needed to understand the developmental fate of germline stem cells.

As observed in the present study, after passage and culture, germline stem cells formed colonies of two distinct types in the presence of LIF and GDNF. This may be because the formation of each is regulated by a different proliferation pathway, namely those involving LIF/gp130 (Kanatsu-Shinohara et al., 2004, 2008; Zhang et al., 2009) and GDNF/GFRa1 signaling (Kubota et al., 2004; Guan et al., 2006; Seandel et al., 2007; Goel et al., 2009; Simon et al., 2009). The former maintains self-replication of embryonic stem cells and primordial germline cells (Zhang et al., 2009). In contrast, the latter facilitates proliferation and differentiation of male germline cells in vitro and in vivo (Kubota et al., 2004; Guan et al., 2006; Seandel et al., 2007). 
After passaging cells from grape-like clusters, the slow and absent proliferation observed in the presence of GDNF and LIF, respectively, could signify that the LIF/gp130 pathway is not involved in the growth of cells from such colonies (Kanatsu-Shinohara et al., 2004, 2008; Zhang et al., 2009). Our experiments also showed that during passaging of ES-like colonies, GDNF-treated cells did not proliferate, whereas those exposed to LIF exhibited rapid growth and colony formation, although this eventually ended because of cell differentiation. LIF appeared unable to inhibit the differentiation of cells within ES-like colonies after a certain degree of proliferation, as the GDNF/GFR $\alpha 1$ signaling pathway is not active in proliferating cells from such colonies, consistent with previous reports (KanatsuShinohara et al., 2004, 2008; Zhang et al., 2009). In addition, proliferating ES-like cells may initiate other differentiation pathways.

Our results show that GDNF and LIF promoted the growth of cells after the passage of grape-like and ES-like colonies, respectively.

\section{Useful method to isolate and culture germline stem cells}

In this study, germline stem cells were isolated and purified with $5-10 \%$ Sertoli cells, capable of growing and serving as a natural feeder layer and niche for primary germline stem cell culture. The use of Sertoli cells as a natural feeder layer in this experiment corroborates a report by Zheng et al. (2013), who utilized these cells for culture in mitomycin C-containing medium. Thus, the Sertoli cell feeder layer is an effective method for the primary culture of germline stem cells.

The relationship between these two cell types is highly intricate. Honaramooz et al. (2007) subcutaneously injected nude mice with pig germline stem cells and Sertoli cells, resulting in their aggregation and the formation of seminiferous tubules. Sertoli cells are unique in their direct interaction with differentiating germline cells, providing nutritional and structural support, as well as a specific microenvironment for spermatogenesis (Kubota et al., 2004). Together, these cells participate in the regulation and secretion of endocrine factors, which are critical for spermatogenesis (Wrobel et al., 1995). Sertoli cells can secrete several growth-stimulating molecules, including fibroblast, transforming, and insulin-like growth factors.

\section{ES-like colonies of germline stem cells}

AKP staining and OCT-4 immunostaining confirmed that the germline stem cells under investigation were pluripotent. However, the hanging drop method illustrated that cells of ES-like colonies aggregated into embryoid bodies, whereas those from grape-like colonies did not, indicating a greater degree of pluripotency in the former than the latter. Using RT-PCR, we also confirmed the findings of a previous study by Simon et al. (2009), who reported that germline stem cells isolated from testes, as well as those cultured in colonies, are pluripotent. For example, germline stem cells expressed Oct-4, a pluripotency gene, and $\mathrm{Dazl}$, associated with the initiation of spermatogenesis. Pluripotent germline stem cells, when cultured, reversed to a more primitive state, forming grape-like and ES-like colonies.

The grape-like colonies retained germline stem cell characteristics because of Dazl expression, which is critical for the maintenance of spermatogenesis. Cells from ES-like colonies demonstrated greater pluripotency, perhaps because they returned to a state similar to that of ES cells, which lack Dazl expression. We speculate that ES-like colony cells cannot directly initiate

Genetics and Molecular Research 15 (4): gmr15048856 
spermatogenesis, and must first undergo differentiation into grape-like colony cells.

Retinoic acid, a vitamin A derivative, can induce the differentiation of ES cells into neural cells. This reagent is most commonly used to promote the generation of neural cells from pluripotent stem cells (Bain et al., 1995). Therefore, in this study, we treated embryoid bodies with retinoic acid to induce the differentiation of germline stem cells into neuronlike cells, which were identified by MAP-2 immunostaining. Our results indicated that male calf germline stem cells can be cultured to form pluripotent stem cells, which in turn can differentiate into various cell types in vitro.

\section{CONCLUSIONS}

Germline stem cells isolated from male calves are pluripotent, and when cultured, can form grape-like clusters and ES-like colonies. GDNF promoted the proliferation of the former, whereas LIF encouraged growth of the latter. Both colony types exhibited pluripotency.

\section{Conflicts of interest}

The authors declare no conflict of interest.

\section{ACKNOWLEDGMENTS}

Research supported by the National International Scientific and Technological Cooperation Project (\#2011DFA30760-2-1) and the Open Projects of Key Laboratory of Animal Genetics, Breeding and Reproduction, College of Heilongjiang Province, China (\#GXZDSYS-2012-07).

\section{REFERENCES}

Aponte PM, Soda T, Teerds KJ, Mizrak SC, et al. (2008). Propagation of bovine spermatogonial stem cells in vitro. Reproduction 136: 543-557. http://dx.doi.org/10.1530/REP-07-0419

Bain G, Kitchens D, Yao M, Huettner JE, et al. (1995). Embryonic stem cells express neuronal properties in vitro. Dev. Biol. 168: 342-357. http://dx.doi.org/10.1006/dbio.1995.1085

Goel S, Fujihara M, Tsuchiya K, Takagi Y, et al. (2009). Multipotential ability of primitive germ cells from neonatal pig testis cultured in vitro. Reprod. Fertil. Dev. 21: 696-708. http://dx.doi.org/10.1071/RD08176

Guan K, Nayernia K, Maier LS, Wagner S, et al. (2006). Pluripotency of spermatogonial stem cells from adult mouse testis. Nature 440: 1199-1203. http://dx.doi.org/10.1038/nature04697

Herrid M, Vignarajan S, Davey R, Dobrinski I, et al. (2006). Successful transplantation of bovine testicular cells to heterologous recipients. Reproduction 132: 617-624. http://dx.doi.org/10.1530/rep.1.01125

Herrid M, Davey RJ, Hutton K, Colditz IG, et al. (2009). A comparison of methods for preparing enriched populations of bovine spermatogonia. Reprod. Fertil. Dev. 21: 393-399. http://dx.doi.org/10.1071/RD08129

Honaramooz A, Megee SO, Rathi R and Dobrinski I (2007). Building a testis: formation of functional testis tissue after transplantation of isolated porcine (Sus scrofa) testis cells. Biol. Reprod. 76: 43-47. http://dx.doi.org/10.1095/ biolreprod.106.054999

Honaramooz A, Megee S, Zeng W, Destrempes MM, et al. (2008). Adeno-associated virus (AAV)-mediated transduction of male germ line stem cells results in transgene transmission after germ cell transplantation. FASEB J. 22: 374-382. http://dx.doi.org/10.1096/fj.07-8935com

Izadyar F, Matthijs-Rijsenbilt JJ, den Ouden K, Creemers LB, et al. (2002a). Development of a cryopreservation protocol for type A spermatogonia. J. Androl. 23: 537-545.

Izadyar F, Spierenberg GT, Creemers LB, den Ouden K, et al. (2002b). Isolation and purification of type A spermatogonia from the bovine testis. Reproduction 124: 85-94.http://dx.doi.org/10.1530/rep.0.1240085

Genetics and Molecular Research 15 (4): gmr15048856 
Kanatsu-Shinohara M, Inoue K, Lee J, Yoshimoto M, et al. (2004). Generation of pluripotent stem cells from neonatal mouse testis. Cell 119: 1001-1012.http://dx.doi.org/10.1016/j.cell.2004.11.011

Kanatsu-Shinohara M, Lee J, Inoue K, Ogonuki N, et al. (2008). Pluripotency of a single spermatogonial stem cell in mice. Biol. Reprod. 78: 681-687.http://dx.doi.org/10.1095/biolreprod.107.066068

Kim KJ, Lee YA, Kim BJ, Kim YH, et al. (2015). Cryopreservation of putative pre-pubertal bovine spermatogonial stem cells by slow freezing. Cryobiology 70: 175-183.http://dx.doi.org/10.1016/j.cryobiol.2015.02.007

Kossack N, Meneses J, Shefi S, Nguyen HN, et al. (2009). Isolation and characterization of pluripotent human spermatogonial stem cell-derived cells. Stem Cells 27: 138-149. http://dx.doi.org/10.1634/stemcells.2008-0439

Kubota H and Brinster RL (2006). Technology insight: In vitro culture of spermatogonial stem cells and their potential therapeutic uses. Nat. Clin. Pract. Endocrinol. Metab. 2: 99-108. http://dx.doi.org/10.1038/ncpendmet0098

Kubota H, Avarbock MR and Brinster RL (2004). Growth factors essential for self-renewal and expansion of mouse spermatogonial stem cells. Proc. Natl. Acad. Sci. USA 101: 16489-16494.http://dx.doi.org/10.1073/pnas.0407063101

Olive V and Cuzin F (2005). The spermatogonial stem cell: from basic knowledge to transgenic technology. Int. J. Biochem. Cell Biol. 37: 246-250. http://dx.doi.org/10.1016/j.biocel.2004.07.017

Seandel M, James D, Shmelkov SV, Falciatori I, et al. (2007). Generation of functional multipotent adult stem cells from GPR125+ germline progenitors. Nature 449: 346-350. http://dx.doi.org/10.1038/nature06129

Simon L, Ekman GC, Kostereva N, Zhang Z, et al. (2009). Direct transdifferentiation of stem/progenitor spermatogonia into reproductive and nonreproductive tissues of all germ layers. Stem Cells 27: 1666-1675.http://dx.doi.org/10.1002/stem.93

Wrobel KH, Bickel D, Kujat R and Schimmel M (1995). Evolution and ultrastructure of the bovine spermatogonia precursor cell line. Cell Tissue Res. 281: 249-259. http://dx.doi.org/10.1007/BF00583394

Zhang P, Huang ZJ, Lv ZH, Li DX, et al. (2009). Study of several factors affecting on preparation of mouse embryonic stem cells. Life Sci. J. 6: 1-4.

Zhao Q, Wang J, Zhang Y, Kou Z, et al. (2010). Generation of histocompatible androgenetic embryonic stem cells using spermatogenic cells. Stem Cells 28: 229-239.

Zheng P, Li DX, Tian YG, Huang H, et al. (2013). Isolation, purification and cryopreservation of cells from neonatal bovine testis. J. Northeast Agric. Univ. 20: 37-42. http://dx.doi.org/10.1016/S1006-8104(13)60006-9

Zheng P, Zhao XW, Zheng XM, Khalid A, et al. (2015). In vitro differentiation of sperm from male germline stem cell. Genet. Mol. Res. 14: 2964-2969. http://dx.doi.org/10.4238/2015.April.10.5

Genetics and Molecular Research 15 (4): gmr15048856 